\title{
Permainan Dadu pada Pengembangan Perilaku Prososial Anak di RA An-Nur Kota Kendari
}

\author{
La Hewi ${ }^{1}$, Surpida ${ }^{2}$
}

Received: 1112 2019 / Accepted: 1312 2019 / Published online: 28122019

(C) 2019 Early Chilhood Islamic Education Study Program

Abstract: The game can not be separated from learning in early childhood. Games that involve several children will establish social relationships between one child and another child. PAUD unit educators pay less attention to stimulation in the development of prosocial behavior of children but most educators focus on providing stimulation for cognitive aspects, language and religious and moral values as an important aspect of development to be stimulated. The dice game is used to stimulate the development of prosocial behavior of early childhood group A RA An-Nur, Kendari City. The research method used is action research. The model chosen for action is the Kemmis and Taggart cycle which has four stages of planning, action, observation and reflection. Data on the development of a child's prosocial behavior were obtained through observation and subsequent documentation analyzed using a percentage. The study was conducted in two cycles, each cycle having three meetings. The results showed that dice games can improve the development of prosocial behavior in early childhood.

Keywords: dice game, child prosocial behavior

\begin{abstract}
Abstrak: Permainan tidak bisa lepas dari pembelajaran pada anak usia dini. Permainan yang melibatkan beberapa anak akan menjalin hubungan sosial antara anak yang satu dengan anak yang lain. Pendidik satuan PAUD kurang memberikan perhatian untuk stimulasi pada perkembangan perilaku prososial anak namun pendidik kebanyakan fokus pada pemberian stimulasi untuk aspek kognitif, bahasa dan nilai agama dan moral sebagai aspek perkembangan yang penting untuk diberikan stimulasi. Permainan dadu digunakan untuk stimulasi perkembangan perilaku prososial anak usia dini kelompok A RA An-Nur Kota Kendari. Metode penelitian yang digunakan adalah penelitian tindakan (action research). Model yang dipilih untuk melakukan tindakan yaitu siklus model Kemmis dan Taggart yang memiliki empat tahapan perencanaan, tindakan, observasi dan refleksi. Data perkembangan perilaku prososial anak diperoleh melalui observasi dan dokumentasi selanjutnya dianalisis dengan menggunakan presentase. Penelitian dilakukan dua siklus, setiap siklus dilakukan tiga kali pertemuan. Hasil penelitian menunjukkan bahwa permainan dadu dapat meningkatkan perkembangan perilaku prososial anak usia dini.
\end{abstract}

Kata kunci : Permainan dadu, Perilaku Prososial Anak

\footnotetext{
${ }^{1}$ Institut Agama Islam Negeri Kendari

${ }^{2}$ RA An-Nur Kota Kendari
} 


\section{PENDAHULUAN}

Kegiatan bermain selalu menarik bagi anak untuk dilakukan secara berkelompok maupun sendiri. Bermain merupakan aktivitas yang menyenangkan dan membawa kebahagiaan bagi anak usia dini. Papalia dan Feldman menyatakan bahwa bermain sebagai aktivitas dan kesibukan anak usia dini memiliki kontribusi terhadap semua aspek perkembangan. Melalui kegiatan bermain anak akan melatih otot-ototnya, mengkoordinasi antara mata dengan gerakannya, menguasai fungsi-fungsi tubuh dengan baik, membuat keputusan dan melalui bermain anak mendapatkan keahlian atau kemampuan baru (Papalia, 2015, p. 285). Lebih lanjut dijelaskan oleh Hurlock bahwa pada masa awal kanak-kanak dikenal dengan sebutan tahap mainan karena seluruh aktivitas kegiatan bermain yang dilakukan oleh anak menggunakan mainan (Hurlock, 1980: 121). Berdasarkan pemaparan yang telah dikemukakan tentang bermain mengandung pengertian bahwa bermain tidak hanya dilakukan untuk kesenangan semata tetapi ada manfaat yang besar yang didapatkan oleh pelaku dari permainan itu yaitu anak usia dini. Suyadi dan Ulfah menyatakan bahwa melalui bermain anak diajak untuk bereksplorasi, menemukan dan memanfaatkan benda-benda yang ada di sekitarnya (Suyadi dan Ulfah, 2013: 34). Zaini menyatakan bahwa bermain adalah metode pembelajaran untuk anak usia dini (Zaini, 2015: 133). Dalam pembelajaran banyak metode dan strategi yang dapat dipilih oleh guru tetapi untuk pendidikan anak usia dini yang paling tepat untuk diterapkan adalah metode bermain. Bermain selalu serius dan menyenangkan sekaligus hiburan bagi anak.

Mulyasa menjelaskan bahwa dalam bermain terdapat beberapa jenis yang dapat digunakan sebagai metode pembelajaran bagi anak usia dini yaitu pertama bermain sosial yaitu kegiatan bermain yang menuntut partisipasi anak untuk melibatkan dirinya dalam proses permainan itu, kedua bermain dengan benda yaitu aktivitas bermain yang dilakukan oleh anak usia dini dengan menggunakan media (benda) dalam kegiatan bermainnya sehingga berimplikasi pada pembelajaran yaitu penggunaan media untuk kegiatan bermain, dan terakhir bermain peran yaitu kegiatan bermain dimana anak berperan sebagai seseorang di luar dirinya untuk menghayati dan memahami peranperan tokoh tersebut dalam kegiatan bermainnya sesuai dengan kenyataan yang ada di dunia nyata (Mulyasa, 2012: 169-173). Permainan dadu berdasarkan penjelasan tentang jenis-jenis bermain termaksud dalam bermain sosial dan bermain dengan benda. Dalam penelitian ini permainan dadu digunakan sebagai media pembelajaran yang dirancang dan dibuat sendiri oleh peneliti dengan bahan berasal dari kardus dan kain flannel, selanjutnya dibentuk seperti kubus yaitu memiliki enam sisi, pada setiap sisi terdapat angka satu sampai angka enam. Adapun cara memainkannya sama seperti memainkan permainan ular tangga yaitu dimainkan secara kelompok, masing-masing kelompok berjumlah dua anak, anak yang pertama berperan sebagai pelempar dadu sementara anak yang kedua berperan sebagai pion yang akan melangkahi beberapa kotak yang berisi huruf abjad secara keseluruhan mulai dari huruf A sampai huruf Z, kelompok yang menang adalah kelompok yang memiliki pion lebih dahulu sampai di huruf terakhir dari abjad. Pemilihan permainan dadu untuk stimulasi aspek perilaku prososial karena adanya temuan penelitian tentang permainan dadu yaitu Andryani, Raga dan Suartama mengemukakan bahwa penerapan metode demonstrasi berbantuan media dadu untuk meningkatkan kemampuan mengenal konsep bilangan pada anak di TK (Andriyani, P. W. S., Raga, G., \& Suartama, 2013: 10). Begitu dengan temuan penelitian oleh Rohmah yang menyatakan bahwa permainan dadu dapat digunakan untuk pengembangan matematika anak usia dini (Rohmah, N., 2016: 44). Sehingga 
beberapa asumsi di atas relevan dengan penelitian yang akan dilakukan oleh peneliti yaitu permainan dadu untuk stimulasi perkembangan perilaku prososial anak.

Peraturan menteri pendidikan dan kebudayaan nomor 137 tentang standar nasional pendidikan anak usia dini menyatakan bahwa ada enam aspek perkembangan yang harus diberikan stimulasi untuk anak usia dini di lembaga-lembaga pendidikan anak usia dini yaitu aspek perkembangan nilai agama dan moral, fisik motorik, kognitif, bahasa, sosial emosional dan seni (Permendikbud, 2014: 2). Indikator perkembangan sosial emosional anak terbagi dalam tiga aspek yaitu aspek kesadaran diri, aspek rasa tanggung jawab untuk diri sendiri dan orang lain serta aspek perilaku prososial. Perkembangan perilaku prososial merupakan salah satu dari beberapa aspek perkembangan yang harus dikembangkan pada peserta didik yang ada di lembagalembaga pendidikan anak usia dini. Desmita menyatakan bahwa perkembangan psikososial berhubungan dengan perubahan-perubahan atau emosi dan kepribadian serta perubahan dalam bagaimana individu berhubungan dengan orang lain (Desmita, 2013: 115). Hurlock menjelaskan bahwa masa kanak-kanak dini yaitu usia 2-6 tahun memiliki periode perkembangan anak berusaha untuk mengendalikan lingkungan dan mulai belajar menyesuaikan diri secara sosial (Hurlock, 2013: 38). Lebih lanjut Parten (1932) dalam Papalia dan Feldman menyatakan bahwa bermain memiliki dimensi sosial dengan bermain anak akan lebih koperatif dan interaktif (Papalia, 2015: 288). Perilaku prososial anak usia dini untuk usia 4-5 tahun memiliki beberapa indikator perkembangan yaitu antara lain menunjukkan antusiasme dalam melakukan permainan kompetitif secara positif, menaati aturan yang berlaku dalam suatu permainan, menghargai orang lain dan menunjukkan rasa simpati (Permendikbud, 2014: 29). Berdasarkan beberapa pemaparan yang telah dikemukakan dapat disintesiskan bahwa perkembangan prososial adalah aspek indikator perkembangan sosial emosional anak yaitu berhubungan dengan kemampuan anak untuk berperilaku sesuai dengan tuntatan sosialnya serta kemampuan anak untuk berinteraksi dengan orang lain.

Pemberian stimulasi pada aspek perkembangan anak usia dini di lembaga PAUD, pada umumnya berfokus pada aspek kognitif, bahasa termaksud nilai agama dan moral. RA An-Nur Kota Kendari sebagai salah satu satuan PAUD yang memberikan layanan pada anak usia 4-6 tahun tidak terlepas dari asumsi di atas yaitu kegiatan pembelajaran yang ada berfokus pada aspek kognitif, bahasa serta nilai agama dan moral. Berdasarkan fakta lapangan yang ditemukan maka peneliti tertarik untuk melakukan kajian tentang permainan dadu untuk perilaku prososial anak. Hal ini didukung oleh temuan penelitian yang telah ada tentang permainan untuk stimulasi perkembangan anak usia dini, peneliti memiliki keyakinan bahwa penggunaan permainan dadu dapat mengembangkan kemampuan perilaku prososial anak usia 4-5 tahun di RA An-Nur Kota Kendari.

\section{METODE}

Penelitian ini menggunakan metode penelitian tindakan (action research). Iskandar menyatakan bahwa penelitian tindakan merupakan aktivitas penelitian yang dilakukan oleh guru dan dosen dalam rangka memperbaiki dan meningkatkan kualitas dan kuantitas proses pembelajaran (Iskandar, 2009:. 20). Penggunaan metode penelitian ini untuk melihat kegiatan belajar di satuan PAUD dengan memberikan tindakan tertentu yang sengaja dilakukan untuk melihat perkembangan dan peningkatan aspek perkembangan perilaku prososial anak usia 4-5 tahun yang ada di RA An-Nur Kota Kendari. Penelitian akan dilakukan selama dua siklus yaitu siklus I dan siklus II, yang masing-masing siklus terdiri dari tiga kali pertemuan. Model penelitian tindakan yang 
dipilih adalah siklus model Kemmis dan Taggart yang memiliki empat tahapan perencanaan, tindakan, observasi dan refleksi (Arikunto, 2009:. 17). Adapun subjek penelitian ini adalah anak kelompok A RA An-Nur Kota Kendari yang berjumlah 20 orang dan terdiri dari 8 orang siswa laki dan 12 orang siswa perempuan yang berada pada rentang usia 4-5 tahun.

Pengumpulan data dalam penelitian ini menggunakan teknik observasi dan dokumentasi pada tindakan pelaksanaan pembelajaran dengan menggunakan permainan dadu. Adapun jenis instrumen yang digunakan dalam penelitian ini yaitu instrumen non tes berupa lembar observasi pada aktivitas dan perilaku yang dilakukan oleh peserta didik, dengan fokus yaitu aspek perilaku prososial anak pada indikator capaian perkembangan yaitu anak antusias dalam melakukan permainan kompetitif, anak menaati aturan dalam bermain, anak menghargai teman dalam sepermainannya, anak menunjukkan simpati pada orang lain.

Analisis data penelitian dilakukan melalui dua cara yaitu teknik analisis kuantitatif deskriptif dan analisis data kualitatif. Analisis kuantitatif deskriptif dilakukan mencari presentase perilaku prososial anak dengan menggunakan rumus yaitu (Purwanto, 2009:. 102) sebagai berikut:

$$
P=\frac{F}{N} \times 100 \%
$$

\author{
Keterangan : \\ $\mathrm{P}=$ Angka Presentase \\ $\mathrm{F}=$ Frekuensi yang Dicari Presentasenya \\ $\mathrm{N}=$ Jumlah Frekuensi atau Banyaknya Individu
}

Perkembangan perilaku prososial anak ditentukan menggunakan kriteria yang ditetapkan oleh peneliti dengan memodifikasi dan berpedoman pada kriteria ketuntasan belajar dari Sudijono (Sudijono, 2010, p. 43) yaitu :
$80 \%-100 \% \quad:$ kriteria baik perkembangan perilaku prososial anak
$60 \%-79 \% \quad:$ kriteria cukup perkembangan perilaku prososial anak
$30 \%-59 \% \quad$ : kriteria kurang baik perkembangan perilaku prososial anak
$0 \%-29 \% \quad:$ kriteria tidak baik perkembangan perilaku prososial anak

\title{
HASIL PENELITIAN DAN ANALISIS
}

Berdasarkan hasil observasi dan dokumentasi tentang capaian perkembangan untuk aspek perilaku prososial anak kelompok A pada rentang usia 4-5 tahun sebelum pelaksanaan siklus satu atau pra tindakan di RA An-Nur Kota Kendari yaitu sebagai berikut:

Tabel 1. Kemampuan Perilaku Prososial Anak Sebelum Siklus 1

\begin{tabular}{|l|l|l|l|l|}
\hline \multicolumn{1}{|c|}{ Perilaku Prososial Anak yang Dinilai } & \multicolumn{3}{|c|}{ Hasil Penilaian } \\
\cline { 2 - 4 } & BB & MB & BSH & BSB \\
\hline anak antusias dalam melakukan permainan kompetitif & $10 \%$ & $15 \%$ & $35 \%$ & $40 \%$ \\
\hline anak menaati aturan dalam bermain & $25 \%$ & $35 \%$ & $20 \%$ & $20 \%$ \\
\hline anak menghargai teman dalam sepermainannya & $15 \%$ & $35 \%$ & $40 \%$ & $10 \%$ \\
\hline anak menunjukkan simpati pada orang lain & $30 \%$ & $30 \%$ & $25 \%$ & $15 \%$ \\
\hline
\end{tabular}

Berdasarkan hasil data pra tindakan perkembangan perilaku prososial anak sesuai dengan tabel 1 diperoleh informasi bahwa pada indikator anak antusias dalam melakukan permainan kompetitif sebanyak $10 \%$ atau 2 orang anak berada pada rentang penilaian belum berkembang, $15 \%$ atau 3 orang anak berada pada rentang penilaian mulai berkembang, $35 \%$ atau 7 orang anak berada pada rentang penilaian berkembang 
sesuai harapan dan $40 \%$ atau 8 orang anak berada pada rentang penilaian berkembang sangat baik. Selanjutnya indikator yang kedua perilaku prososial anak menaati aturan dalam bermain sebanyak $25 \%$ atau 5 orang anak berada pada rentang penilaian belum berkembang, 35\% atau 7 orang anak berada pada rentang penilaian mulai berkembang, $20 \%$ atau 4 orang anak berada pada rentang penilaian berkembang sesuai harapan dan $20 \%$ atau 4 orang anak berada pada rentang penilaian berkembang sangat baik. Pada indikator yang ketiga perilaku prososial anak menghargai teman dalam sepermainannya sebanyak $15 \%$ atau 3 orang anak berada pada rentang penilaian belum berkembang, $35 \%$ atau 7 orang anak berada pada rentang penilaian mulai berkembang, $40 \%$ atau 8 anak berada rentang penilaian berkembang sesuai harapan dan $10 \%$ atau 2 orang anak berada pada rentang penilaian berkembang sangat baik. Indikator perilaku prososial anak yang terakhir yang diamati yaitu anak menunjukkan simpati pada orang lain sebanyak $30 \%$ atau 6 orang anak berada pada rentang penilaian belum berkembang, $30 \%$ atau 6 orang anak berada pada rentang penilaian mulai berkembang, 25\% atau 5 anak berada rentang penilaian berkembang sesuai harapan dan $15 \%$ atau 3 orang anak berada pada rentang penilaian berkembang sangat baik.

\section{Perkembangan Perilaku Prososial Siklus 1}

Data perkembangan perilaku prososial anak yang diperoleh sebelum pelaksanaan siklus satu atau pra tindakan, selanjutnya ditindaklanjuti oleh peneliti dengan menyusun perencanaan untuk melaksanakan tindakan penggunaan permainan dadu untuk perkembangan perilaku prososial anak usia 4-5 tahun di RA An-Nur Kota Kendari. Pelaksanaan tindakan siklus satu dilaksanakan selama 3 kali pertemuan yaitu pada tanggal 21-23 oktober 2019. Data yang diperoleh dari pelaksanaan siklus satu dapat dilihat pada tabel di bawah ini:

Tabel 2. Kemampuan Perilaku Prososial Anak Siklus Satu

\begin{tabular}{|c|c|c|c|c|c|c|c|c|c|c|c|c|}
\hline \multirow[b]{2}{*}{$\begin{array}{l}\text { Perilaku Prososial } \\
\text { Anak yang Dinilai }\end{array}$} & \multicolumn{4}{|c|}{ Pertemuan 1} & \multicolumn{4}{|c|}{ Pertemuan 2} & \multicolumn{4}{|c|}{ Pertemuan 3} \\
\hline & $\mathrm{BB}$ & $\mathrm{MB}$ & $\begin{array}{l}\mathrm{BS} \\
\mathrm{H}\end{array}$ & $\begin{array}{l}\mathrm{BS} \\
\mathrm{B}\end{array}$ & $\mathrm{BB}$ & MB & $\begin{array}{l}\mathrm{BS} \\
\mathrm{H}\end{array}$ & $\begin{array}{l}\text { BS } \\
\text { B }\end{array}$ & $\mathrm{BB}$ & $\begin{array}{l}\mathrm{M} \\
\mathrm{B}\end{array}$ & $\begin{array}{l}\mathrm{BS} \\
\mathrm{H}\end{array}$ & $\begin{array}{l}\text { BS } \\
\text { B }\end{array}$ \\
\hline $\begin{array}{l}\text { anak antusias dalam } \\
\text { melakukan permainan } \\
\text { kompetitif }\end{array}$ & $\begin{array}{l}5 \\
\%\end{array}$ & $\begin{array}{l}5 \\
\%\end{array}$ & $\begin{array}{l}40 \\
\%\end{array}$ & $\begin{array}{l}50 \\
\%\end{array}$ & - & $\begin{array}{l}5 \\
\%\end{array}$ & $\begin{array}{l}30 \\
\%\end{array}$ & $\begin{array}{l}65 \\
\%\end{array}$ & - & - & $\begin{array}{l}25 \\
\%\end{array}$ & $\begin{array}{l}75 \\
\%\end{array}$ \\
\hline $\begin{array}{l}\text { anak menaati aturan } \\
\text { dalam bermain }\end{array}$ & $\begin{array}{l}15 \\
\%\end{array}$ & $\begin{array}{l}20 \\
\%\end{array}$ & $\begin{array}{l}35 \\
\%\end{array}$ & $\begin{array}{l}30 \\
\%\end{array}$ & $\begin{array}{l}5 \\
\% \\
\end{array}$ & $\begin{array}{l}20 \\
\%\end{array}$ & $\begin{array}{l}35 \\
\%\end{array}$ & $\begin{array}{l}40 \\
\%\end{array}$ & - & $\begin{array}{l}10 \\
\%\end{array}$ & $\begin{array}{l}35 \\
\%\end{array}$ & $\begin{array}{l}55 \\
\%\end{array}$ \\
\hline $\begin{array}{l}\text { anak menghargai } \\
\text { teman dalam } \\
\text { sepermainannya }\end{array}$ & $\begin{array}{l}10 \\
\%\end{array}$ & $\begin{array}{l}30 \\
\%\end{array}$ & $\begin{array}{l}45 \\
\%\end{array}$ & $\begin{array}{l}15 \\
\%\end{array}$ & - & $\begin{array}{l}25 \\
\%\end{array}$ & $\begin{array}{l}40 \\
\%\end{array}$ & $\begin{array}{l}35 \\
\%\end{array}$ & - & $\begin{array}{l}15 \\
\%\end{array}$ & $\begin{array}{l}25 \\
\%\end{array}$ & $\begin{array}{l}60 \\
\%\end{array}$ \\
\hline $\begin{array}{l}\text { anak menunjukkan } \\
\text { simpati pada orang } \\
\text { lain }\end{array}$ & $\begin{array}{l}20 \\
\%\end{array}$ & $\begin{array}{l}25 \\
\%\end{array}$ & $\begin{array}{l}35 \\
\%\end{array}$ & $\begin{array}{l}20 \\
\%\end{array}$ & $\begin{array}{l}15 \\
\%\end{array}$ & $\begin{array}{l}20 \\
\%\end{array}$ & $\begin{array}{l}30 \\
\%\end{array}$ & $\begin{array}{l}35 \\
\%\end{array}$ & $\begin{array}{l}5 \\
\%\end{array}$ & $\begin{array}{l}25 \\
\%\end{array}$ & $\begin{array}{l}30 \\
\%\end{array}$ & $\begin{array}{l}40 \\
\%\end{array}$ \\
\hline
\end{tabular}

Setelah dilakukan tindakan pada siklus satu yaitu penggunaan permainan dadu untuk perkembangan perilaku prososial anak usia 4-5 tahun di RA An-Nur Kota Kendari diperoleh data sebagai berikut:

1. Pada pertemuan pertama dari pelaksanaan tindakan siklus satu yaitu pada indikator anak antusias dalam melakukan permainan kompetitif sebanyak 5\% atau 1 orang anak berada pada rentang penilaian belum berkembang, 5\% atau 1 orang anak berada pada rentang penilaian mulai berkembang, $40 \%$ atau 8 orang anak berada pada rentang penilaian berkembang sesuai harapan dan $50 \%$ atau 10 orang anak berada pada rentang penilaian berkembang sangat baik. Selanjutnya indikator yang kedua 
perilaku prososial anak menaati aturan dalam bermain sebanyak 15\% atau 3 orang anak berada pada rentang penilaian belum berkembang, 20\% atau 4 orang anak berada pada rentang penilaian mulai berkembang, 35\% atau 7 orang anak berada pada rentang penilaian berkembang sesuai harapan dan 30\% atau 6 orang anak berada pada rentang penilaian berkembang sangat baik. Pada indikator yang ketiga perilaku prososial anak menghargai teman dalam sepermainannya sebanyak $10 \%$ atau 2 orang anak berada pada rentang penilaian belum berkembang, 30\% atau 6 orang anak berada pada rentang penilaian mulai berkembang, 45\% atau 9 anak berada rentang penilaian berkembang sesuai harapan dan $15 \%$ atau 3 orang anak berada pada rentang penilaian berkembang sangat baik. Indikator perilaku prososial anak yang terakhir yang diamati yaitu anak menunjukkan simpati pada orang lain sebanyak $20 \%$ atau 4 orang anak berada pada rentang penilaian belum berkembang, $25 \%$ atau 5 orang anak berada pada rentang penilaian mulai berkembang, 35\% atau 7 anak berada rentang penilaian berkembang sesuai harapan dan $20 \%$ atau 4 orang anak berada pada rentang penilaian berkembang sangat baik.

2. Pada pertemuan kedua dari pelaksanaan tindakan siklus satu yaitu pada indikator anak antusias dalam melakukan permainan kompetitif sudah tidak ada anak pada rentang penilaian belum berkembang, 5\% atau 1 orang anak berada pada rentang penilaian mulai berkembang, $30 \%$ atau 6 orang anak berada pada rentang penilaian berkembang sesuai harapan dan $65 \%$ atau 13 orang anak berada pada rentang penilaian berkembang sangat baik. Selanjutnya indikator yang kedua perilaku prososial anak menaati aturan dalam bermain sebanyak $5 \%$ atau 1 orang anak berada pada rentang penilaian belum berkembang, $20 \%$ atau 4 orang anak berada pada rentang penilaian mulai berkembang, $35 \%$ atau 7 orang anak berada pada rentang penilaian berkembang sesuai harapan dan $40 \%$ atau 8 orang anak berada pada rentang penilaian berkembang sangat baik. Pada indikator yang ketiga perilaku prososial anak menghargai teman dalam sepermainannya sudah tidak ada anak pada rentang penilaian belum berkembang, $25 \%$ atau 5 orang anak berada pada rentang penilaian mulai berkembang, $40 \%$ atau 8 anak berada rentang penilaian berkembang sesuai harapan dan $35 \%$ atau 7 orang anak berada pada rentang penilaian berkembang sangat baik. Indikator perilaku prososial anak yang terakhir yang diamati yaitu anak menunjukkan simpati pada orang lain sebanyak $15 \%$ atau 3 orang anak berada pada rentang penilaian belum berkembang, 20\% atau 4 orang anak berada pada rentang penilaian mulai berkembang, 30\% atau 6 anak berada rentang penilaian berkembang sesuai harapan dan $35 \%$ atau 7 orang anak berada pada rentang penilaian berkembang sangat baik.

3. Pada pertemuan ketiga dari pelaksanaan tindakan siklus satu yaitu pada indikator anak antusias dalam melakukan permainan kompetitif sudah tidak ada anak pada rentang penilaian belum berkembang dan mulai berkembang, $25 \%$ atau 5 orang anak berada pada rentang penilaian berkembang sesuai harapan dan $75 \%$ atau 15 orang anak berada pada rentang penilaian berkembang sangat baik. Selanjutnya indikator yang kedua perilaku prososial anak menaati aturan dalam bermain sudah tidak ada anak pada rentang penilaian belum berkembang, $10 \%$ atau 2 orang anak berada pada rentang penilaian mulai berkembang, $35 \%$ atau 7 orang anak berada pada rentang penilaian berkembang sesuai harapan dan $55 \%$ atau 11 orang anak berada pada rentang penilaian berkembang sangat baik. Pada indikator yang ketiga perilaku prososial anak menghargai teman dalam sepermainannya sudah tidak ada anak pada rentang penilaian belum berkembang, 15\% atau 3 orang anak berada pada rentang 
penilaian mulai berkembang, $25 \%$ atau 5 anak berada rentang penilaian berkembang sesuai harapan dan $60 \%$ atau 12 orang anak berada pada rentang penilaian berkembang sangat baik. Indikator perilaku prososial anak yang terakhir yang diamati yaitu anak menunjukkan simpati pada orang lain sebanyak 5\% atau 1 orang anak berada pada rentang penilaian belum berkembang, $25 \%$ atau 5 orang anak berada pada rentang penilaian mulai berkembang, 30\% atau 6 anak berada rentang penilaian berkembang sesuai harapan dan $40 \%$ atau 8 orang anak berada pada rentang penilaian berkembang sangat baik.

\section{Perkembangan Perilaku Prososial Siklus 2}

Berdasarkan data yang diperoleh peneliti dari pelaksanaan tindakan siklus satu diperoleh informasi bahwa capaian keseluruhan indikator perkembangan perilaku prososial anak berada pada kategori cukup dan kurang baik sehingga peneliti memutuskan untuk meneruskan pemberian tindakan ke siklus kedua. Pelaksanaan tindakan siklus kedua dilaksanakan selama 3 kali pertemuan yaitu pada tanggal 28-30 oktober 2019. Data yang diperoleh dari pelaksanaan siklus kedua dapat dilihat pada tabel di bawah ini:

Tabel 3. Kemampuan Perilaku Prososial Anak Siklus Dua

\begin{tabular}{|c|c|c|c|c|c|c|c|c|c|c|c|c|}
\hline \multirow[b]{2}{*}{$\begin{array}{c}\text { Perilaku Prososial Anak } \\
\text { yang Dinilai }\end{array}$} & \multicolumn{4}{|c|}{ Pertemuan 1} & \multicolumn{4}{|c|}{ Pertemuan 2} & \multicolumn{4}{|c|}{ Pertemuan 3} \\
\hline & $\mathrm{BB}$ & MB & $\begin{array}{l}\mathrm{BS} \\
\mathrm{H}\end{array}$ & $\begin{array}{l}\mathrm{BS} \\
\mathrm{B}\end{array}$ & $\mathrm{BB}$ & $\mathrm{MB}$ & $\begin{array}{l}\mathrm{BS} \\
\mathrm{H}\end{array}$ & $\begin{array}{l}\mathrm{BS} \\
\mathrm{B}\end{array}$ & $\begin{array}{l}\mathrm{B} \\
\mathrm{B}\end{array}$ & $\begin{array}{l}\mathrm{M} \\
\mathrm{B}\end{array}$ & $\begin{array}{l}\mathrm{BS} \\
\mathrm{H}\end{array}$ & $\begin{array}{l}\mathrm{BS} \\
\mathrm{B}\end{array}$ \\
\hline $\begin{array}{l}\text { anak antusias dalam } \\
\text { melakukan permainan } \\
\text { kompetitif }\end{array}$ & - & - & $\begin{array}{l}20 \\
\%\end{array}$ & $\begin{array}{l}80 \\
\%\end{array}$ & - & - & $\begin{array}{l}15 \\
\%\end{array}$ & $\begin{array}{l}85 \\
\%\end{array}$ & - & - & $\begin{array}{l}10 \\
\%\end{array}$ & $\begin{array}{l}90 \\
\%\end{array}$ \\
\hline $\begin{array}{l}\text { anak menaati aturan } \\
\text { dalam bermain }\end{array}$ & - & - & $\begin{array}{l}40 \\
\%\end{array}$ & $\begin{array}{l}60 \\
\%\end{array}$ & - & - & $\begin{array}{l}25 \\
\%\end{array}$ & $\begin{array}{l}75 \\
\%\end{array}$ & - & - & $\begin{array}{l}15 \\
\%\end{array}$ & $\begin{array}{l}85 \\
\%\end{array}$ \\
\hline $\begin{array}{l}\text { anak menghargai teman } \\
\text { dalam sepermainannya }\end{array}$ & - & $\begin{array}{l}10 \\
\%\end{array}$ & $\begin{array}{l}25 \\
\%\end{array}$ & $\begin{array}{l}65 \\
\%\end{array}$ & - & - & $\begin{array}{l}30 \\
\%\end{array}$ & $\begin{array}{l}70 \\
\%\end{array}$ & - & - & $\begin{array}{l}20 \\
\%\end{array}$ & $\begin{array}{l}80 \\
\%\end{array}$ \\
\hline $\begin{array}{l}\text { anak menunjukkan } \\
\text { simpati pada orang lain }\end{array}$ & - & $\begin{array}{l}25 \\
\%\end{array}$ & $\begin{array}{l}30 \\
\%\end{array}$ & $\begin{array}{l}45 \\
\%\end{array}$ & - & $\begin{array}{l}15 \\
\%\end{array}$ & $\begin{array}{l}30 \\
\%\end{array}$ & $\begin{array}{l}55 \\
\%\end{array}$ & - & $\begin{array}{l}5 \\
\%\end{array}$ & $\begin{array}{l}25 \\
\%\end{array}$ & $\begin{array}{l}70 \\
\%\end{array}$ \\
\hline
\end{tabular}

Setelah dilakukan tindakan pada siklus kedua yaitu penggunaan permainan dadu untuk perkembangan perilaku prososial anak usia 4-5 tahun di RA An-Nur Kota Kendari diperoleh data sebagai berikut:

1. Pada pertemuan pertama dari pelaksanaan tindakan siklus kedua yaitu pada indikator anak antusias dalam melakukan permainan kompetitif sudah tidak ada anak pada rentang penilaian belum berkembang dan mulai berkembang, 20\% atau 4 orang anak berada pada rentang penilaian berkembang sesuai harapan dan $80 \%$ atau 16 orang anak berada pada rentang penilaian berkembang sangat baik. Selanjutnya indikator yang kedua perilaku prososial anak menaati aturan dalam bermain sudah tidak ada anak pada rentang penilaian belum berkembang dan mulai berkembang, $40 \%$ atau 8 orang anak berada pada rentang penilaian berkembang sesuai harapan dan $60 \%$ atau 12 orang anak berada pada rentang penilaian berkembang sangat baik. Pada indikator yang ketiga perilaku prososial anak menghargai teman dalam sepermainannya sudah tidak ada anak pada rentang penilaian belum berkembang, $10 \%$ atau 2 orang anak berada pada rentang penilaian mulai berkembang, 25\% atau 5 anak berada rentang penilaian berkembang sesuai harapan dan $65 \%$ atau 13 orang anak berada pada rentang penilaian berkembang sangat baik. Indikator perilaku prososial anak yang terakhir yang diamati yaitu anak menunjukkan simpati pada orang lain tidak ada anak pada rentang penilaian belum berkembang, $25 \%$ atau 5 orang anak berada pada 
rentang penilaian mulai berkembang, $30 \%$ atau 6 anak berada rentang penilaian berkembang sesuai harapan dan $45 \%$ atau 9 orang anak berada pada rentang penilaian berkembang sangat baik.

2. Pada pertemuan kedua dari pelaksanaan tindakan siklus kedua yaitu pada indikator anak antusias dalam melakukan permainan kompetitif sudah tidak ada anak pada rentang penilaian belum berkembang dan mulai berkembang, $15 \%$ atau 3 orang anak berada pada rentang penilaian berkembang sesuai harapan dan $85 \%$ atau 17 orang anak berada pada rentang penilaian berkembang sangat baik. Selanjutnya indikator yang kedua perilaku prososial anak menaati aturan dalam bermain sudah tidak ada anak pada rentang penilaian belum berkembang dan mulai berkembang, 25\% atau 5 orang anak berada pada rentang penilaian berkembang sesuai harapan dan $75 \%$ atau 15 orang anak berada pada rentang penilaian berkembang sangat baik. Pada indikator yang ketiga perilaku prososial anak menghargai teman dalam sepermainannya sudah tidak ada anak pada rentang penilaian belum berkembang dan mulai berkembang, $30 \%$ atau 6 anak berada rentang penilaian berkembang sesuai harapan dan $70 \%$ atau 14 orang anak berada pada rentang penilaian berkembang sangat baik. Indikator perilaku prososial anak yang terakhir yang diamati yaitu anak menunjukkan simpati pada orang lain tidak ada anak pada rentang penilaian belum berkembang, $15 \%$ atau 3 orang anak berada pada rentang penilaian mulai berkembang, 30\% atau 6 anak berada rentang penilaian berkembang sesuai harapan dan 55\% atau 11 orang anak berada pada rentang penilaian berkembang sangat baik.

3. Pada pertemuan ketiga dari pelaksanaan tindakan siklus kedua yaitu pada indikator anak antusias dalam melakukan permainan kompetitif sudah tidak ada anak pada rentang penilaian belum berkembang dan mulai berkembang, $10 \%$ atau 2 orang anak berada pada rentang penilaian berkembang sesuai harapan dan $90 \%$ atau 18 orang anak berada pada rentang penilaian berkembang sangat baik. Selanjutnya indikator yang kedua perilaku prososial anak menaati aturan dalam bermain sudah tidak ada anak pada rentang penilaian belum berkembang dan mulai berkembang, 15\% atau 3 orang anak berada pada rentang penilaian berkembang sesuai harapan dan $85 \%$ atau 17 orang anak berada pada rentang penilaian berkembang sangat baik. Pada indikator yang ketiga perilaku prososial anak menghargai teman dalam sepermainannya sudah tidak ada anak pada rentang penilaian belum berkembang dan mulai berkembang, $20 \%$ atau 4 anak berada rentang penilaian berkembang sesuai harapan dan $80 \%$ atau 16 orang anak berada pada rentang penilaian berkembang sangat baik. Indikator perilaku prososial anak yang terakhir yang diamati yaitu anak menunjukkan simpati pada orang lain tidak ada anak pada rentang penilaian belum berkembang, 5\% atau 1 orang anak berada pada rentang penilaian mulai berkembang, 25\% atau 5 anak berada rentang penilaian berkembang sesuai harapan dan $70 \%$ atau 14 orang anak berada pada rentang penilaian berkembang sangat baik.

\section{PEMBAHASAN}

Perkembangan perilaku prososial anak kelompok A usia 4-5 tahun di RA An-Nur Kota Kendari dapat diidentifikasi dengan baik dan teratur dengan menampilkan grafik kemampuan perilaku prososial anak sebelum dan sesudah diberikan tindakan yaitu permainan dadu untuk perilaku prososial anak, sebagai berikut: 


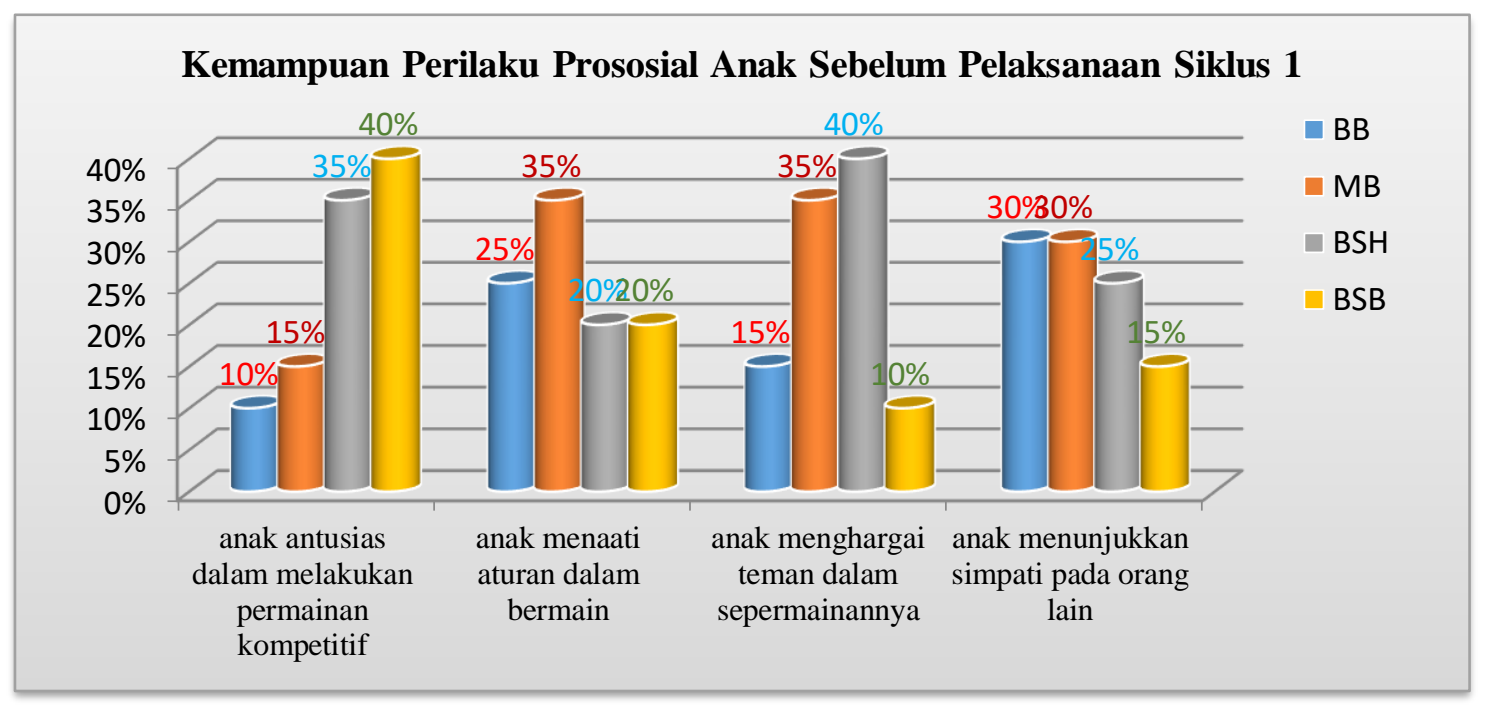

Berdasarkan data yang ada dalam grafik kemampuan perilaku prososial anak sebelum pelaksanaan siklus satu menunjukkan bahwa pada indikator anak antusias dalam melakukan permainan kompetitif sebanyak $40 \%$ atau 8 orang anak berada pada rentang penilaian berkembang sangat baik, $35 \%$ atau 7 orang anak berada pada rentang penilaian berkembang sesuai harapan, $15 \%$ atau 3 orang anak berada pada rentang penilaian mulai berkembang dan $10 \%$ atau 2 orang anak berada pada rentang penilaian belum berkembang. Selanjutnya indikator yang kedua perilaku prososial anak menaati aturan dalam bermain sebanyak $35 \%$ atau 7 orang anak berada pada rentang penilaian mulai berkembang, $25 \%$ atau 5 orang anak berada pada rentang penilaian belum berkembang, $20 \%$ atau 4 orang anak berada pada rentang penilaian berkembang sesuai harapan dan $20 \%$ atau 4 orang anak berada pada rentang penilaian berkembang sangat baik. Pada indikator yang ketiga perilaku prososial anak menghargai teman dalam sepermainannya sebanyak $40 \%$ atau 8 anak berada rentang penilaian berkembang sesuai harapan, $35 \%$ atau 7 orang anak berada pada rentang penilaian mulai berkembang, $15 \%$ atau 3 orang anak berada pada rentang penilaian belum berkembang dan $10 \%$ atau 2 orang anak berada pada rentang penilaian berkembang sangat baik. Indikator perilaku prososial anak yang terakhir yang diamati yaitu anak menunjukkan simpati pada orang lain sebanyak $30 \%$ atau 6 orang anak berada pada rentang penilaian belum berkembang, $30 \%$ atau 6 orang anak berada pada rentang penilaian mulai berkembang, $25 \%$ atau 5 anak berada rentang penilaian berkembang sesuai harapan dan $15 \%$ atau 3 orang anak berada pada rentang penilaian berkembang sangat baik.

Hasil penilaian kemampuan perilaku prososial anak berdasarkan grafik kemampuan perilaku prososial anak sebelum pelaksanaan siklus satu diperoleh informasi bahwa empat indikator perkembangan perilaku prososial anak dominan berada pada penilaian berkembang sangat baik, mulai berkembang, berkembang sesuai harapan dan belum berkembang dengan kategori ketuntasan perkembangan yaitu tidak baik dan kurang baik, hal ini berarti bahwa capaian perkembangan anak secara keseluruhan masih sangat rendah.

Selanjutnya diberikan tindakan pada siklus satu sebanyak tiga kali pertemuan berupa penggunaan permainan dadu untuk perkembangan perilaku prososial anak kemudian dilakukan penilaian untuk melihat capaian perkembangan anak. Adapun capaian perkembangan prososial anak untuk siklus satu yaitu sebagai berikut: 


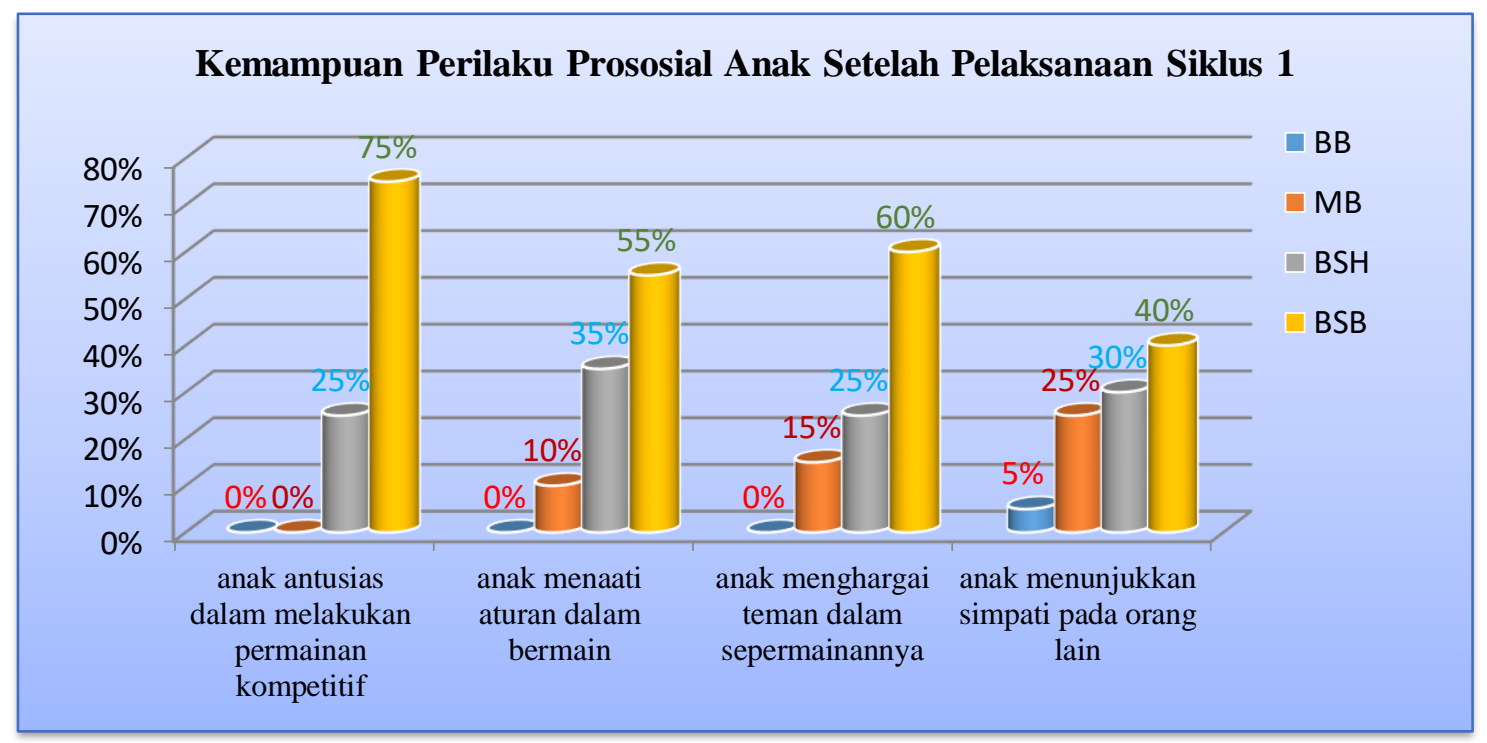

Capaian perkembangan perilaku prososial anak pada indikator anak antusias dalam melakukan permainan kompetitif sebanyak $75 \%$ atau 15 orang anak berada pada rentang penilaian berkembang sangat baik, 25\% atau 5 orang anak berada pada rentang penilaian berkembang sesuai harapan dan tidak ditemukan lagi ada anak yang berada rentang penilaian belum berkembang dan mulai berkembang. Selanjutnya indikator yang kedua perilaku prososial anak menaati aturan dalam bermain sebanyak $55 \%$ atau 11 orang anak berada pada rentang penilaian berkembang sangat baik, 35\% atau 7 orang anak berada pada rentang penilaian berkembang sesuai harapan, $10 \%$ atau 2 orang anak berada pada rentang penilaian mulai berkembang dan sudah tidak ditemukan lagi ada anak pada rentang penilaian belum berkembang. Pada indikator yang ketiga perilaku prososial anak menghargai teman dalam sepermainannya sebanyak $60 \%$ atau 12 orang anak berada pada rentang penilaian berkembang sangat baik, 25\% atau 5 anak berada rentang penilaian berkembang sesuai harapan, $15 \%$ atau 3 orang anak berada pada rentang penilaian mulai berkembang dan sudah tidak ditemukan lagi ada anak pada rentang penilaian belum berkembang. Indikator perilaku prososial anak yang terakhir yang diamati yaitu anak menunjukkan simpati pada orang lain sebanyak $40 \%$ atau 8 orang anak berada pada rentang penilaian berkembang sangat baik, 30\% atau 6 anak berada rentang penilaian berkembang sesuai harapan, $25 \%$ atau 5 orang anak berada pada rentang penilaian mulai berkembang dan $5 \%$ atau 1 orang anak berada pada rentang penilaian belum berkembang.

Hasil penilaian kemampuan perilaku prososial anak berdasarkan grafik setelah pelaksanaan siklus satu menunjukkan bahwa empat aspek indikator perkembangan perilaku prososial dominan berada pada penilaian berkembang sangat baik namun kategori ketuntasan perkembangan yaitu kurang baik dan cukup hal ini berarti bahwa capaian perkembangan anak secara keseluruhan masih cukup rendah. Oleh karena itu pemberian tindakan yaitu penggunaan permainan dadu untuk perkembangan perilaku prososial anak dilanjutkan pada siklus kedua. Adapun capaian perkembangan perilaku prososial anak untuk siklus dua yaitu sebagai berikut: 


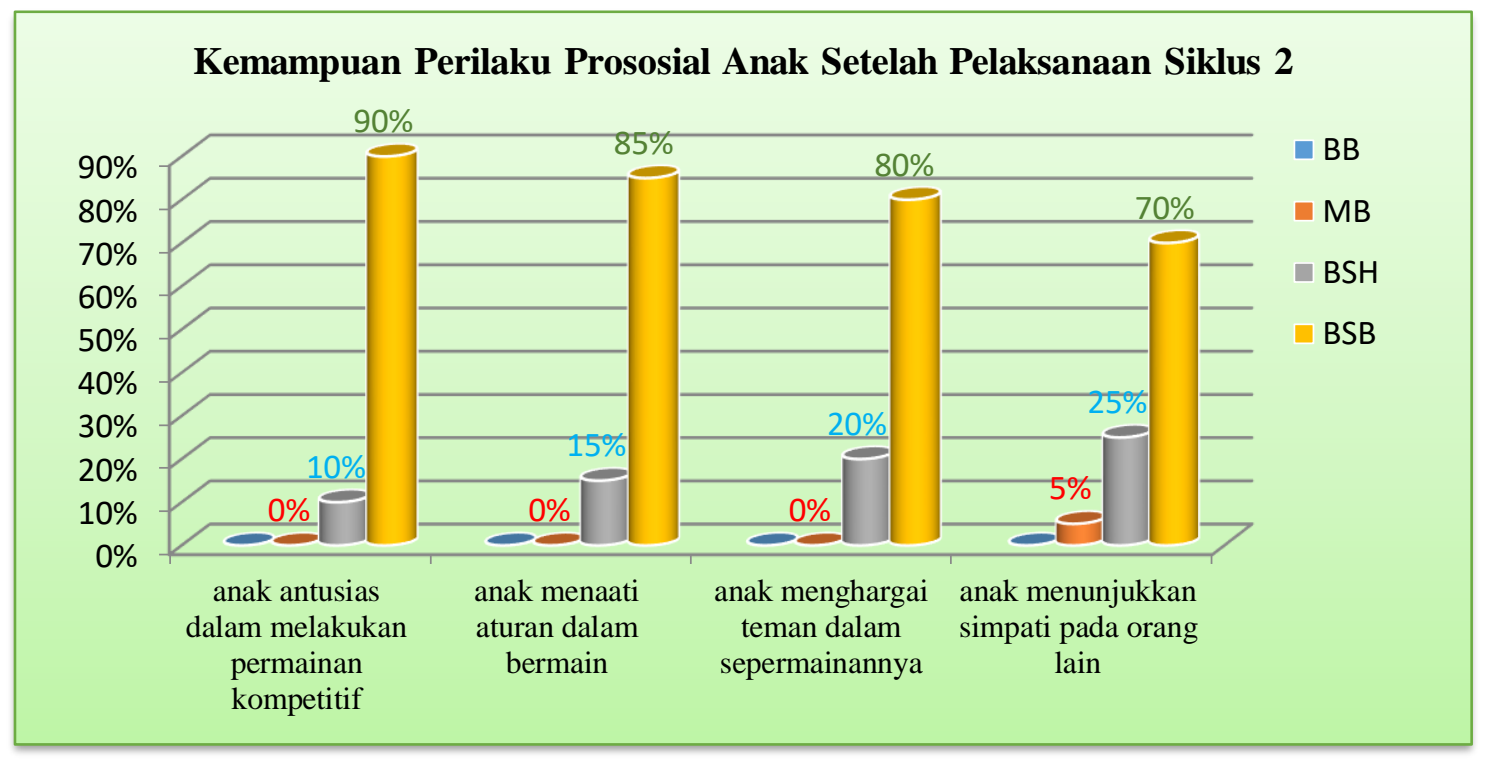

Capaian perkembangan perilaku prososial anak pada indikator anak antusias dalam melakukan permainan kompetitif sebanyak $90 \%$ atau 18 orang anak berada pada rentang penilaian berkembang sangat baik, $10 \%$ atau 2 orang anak berada pada rentang penilaian berkembang sesuai harapan dan sudah tidak ada anak pada rentang penilaian belum berkembang dan mulai berkembang. Selanjutnya indikator yang kedua perilaku prososial anak menaati aturan dalam bermain sebanyak $85 \%$ atau 17 orang anak berada pada rentang penilaian berkembang sangat baik, $15 \%$ atau 3 orang anak berada pada rentang penilaian berkembang sesuai harapan dan sudah tidak ada anak pada rentang penilaian belum berkembang dan mulai berkembang. Pada indikator yang ketiga perilaku prososial anak menghargai teman dalam sepermainannya sebanyak $80 \%$ atau 16 orang anak berada pada rentang penilaian berkembang sangat baik, 20\% atau 4 anak berada rentang penilaian berkembang sesuai harapan dan sudah tidak ditemukan ada anak yang berada rentang penilaian belum berkembang dan mulai berkembang. Indikator perilaku prososial anak yang terakhir yang diamati yaitu anak menunjukkan simpati pada orang lain sebanyak $70 \%$ atau 14 orang anak berada pada rentang penilaian berkembang sangat baik, $25 \%$ atau 5 anak berada rentang penilaian berkembang sesuai harapan, $5 \%$ atau 1 orang anak berada pada rentang penilaian mulai berkembang sementara untuk kategori anak yang berada pada rentang penilaian belum berkembang sudah tidak ditemukan.

Hasil penilaian kemampuan perilaku prososial anak berdasarkan grafik setelah pelaksanaan siklus kedua menunjukkan bahwa empat aspek indikator perkembangan perilaku prososial dominan berada pada penilaian berkembang sangat baik dengan kategori ketuntasan perkembangan yaitu baik untuk indikator perkembangan perilaku prososial; anak antusias dalam melakukan permainan kompetitif yaitu 90\%, anak menaati aturan dalam bermain yaitu $85 \%$ dan anak menghargai teman dalam sepermainannya yaitu $80 \%$ sementara untuk kategori cukup pada indikator perkembangan perilaku prososial; anak menunjukkan simpati pada orang lain yaitu 70\%. Berdasarkan hasil yang didapatkan setelah pelaksanaan siklus kedua maka pemberian tindakan yaitu penggunaan permainan dadu untuk perkembangan perilaku prososial anak dihentikan oleh peneliti.

Berdasarkan temuan penelitian yang telah kemukakan oleh peneliti bahwa penggunaan permainan dadu untuk stimulasi perkembangan perilaku prososial anak usia 
4-5 tahun pada empat indikator perkembangan yaitu anak antusias dalam melakukan permainan kompetitif, anak menaati aturan dalam bermain, anak menghargai teman dalam sepermainannya dan anak menunjukkan simpati pada orang lain memiliki capaian perkembangan pada penilaian yaitu berkembang sangat baik (BSB) dengan kategori ketuntasan perkembangan baik $(90 \%, 85 \%$ dan $80 \%)$ dan cukup $(70 \%)$. Temuan penelitian ini sesuai dengan temuan peneliti yang lain yang lebih dulu melakukan penelitian tentang permainan untuk perkembangan kemampuan anak usia dini, misalnya Ananda dan Fadhilaturrahmi meneliti tentang permainan kolaboratif untuk kemampuan prososial anak di kelompok bermain menyimpulkan bahwa permainan kolaboratif dapat meningkatkan kemampuan prososial anak KB (Ananda, Rizki dan Fadhilaturrahmi, 2018, p. 20). Begitu juga dengan penelitian yang dilakukan oleh Duha dan Widiastuti yang menyatakan bahwa kemampuan prososial anak dapat ditingkatkan melalui permainan role playing (Duha, Refisi dan Widiastuti, 2018, p. 86). Sementara untuk penelitian yang secara khusus tentang permainan dadu misalnya penelitian yang dilakukan oleh Rohmawati dan Simatupang menyatakan bahwa permainan dadu modifikasi warna warni berpengaruh pada kemampuan menghitung anak usia 5-6 tahun (Rohmawati, Mirsa dan Simatupang, 2017, p. 4). Begitu juga dengan penelitian yang dilakukan oleh Joni yang menyatakan bahwa permainan dadu dapat meningkatkan perkembangan kognitif anak dalam berhitung (Joni, 2016, p. 10). Nurbayani dalam temuan disertainya mengemukakan bahwa penerapan bermain dadu geometri berpengaruh terhadap keterampilan sosial anak usia dini (Nurbayani, 2011). Berdasarkan temuan penelitian yang telah dikemukakan di atas, baik temuan pada penelitian ini yang menyatakan bahwa permainan dadu sangat baik untuk perkembangan perilaku prososial anak usia 4-5 tahun maupun temuan pada penelitianpenelitian terdahulu menunjukkan bahwa permainan sangat tepat untuk digunakan sebagai salah satu metode, teknik ataupun media dalam pembelajaran anak usia dini.

\section{SIMPULAN DAN SARAN}

Berdasarkan hasil dan pembahasan yang telah dikemukakan, dapat diambil simpulan bahwa permainan dadu dapat mengembangkan perilaku prososial anak usia 45 tahun di RA An-Nur Kota Kendari pada empat indikator capaian perkembangan yaitu anak antusias dalam melakukan permainan kompetitif, anak menaati aturan dalam bermain, anak menghargai teman dalam sepermainannya, anak menunjukkan simpati pada orang lain.

Adapun saran dari peneliti setelah melakukan penelitian ini yaitu kepada pendidik di lembaga PAUD dapat memberikan stimulasi perkembangan yang bervariasi untuk semua aspek perkembangan usia dini, tidak hanya berfokus pada salah satu atau beberapa aspek perkembangan, salah satu media yang tepat untuk stimulasi perkembangan perilaku prososial anak yaitu permainan dadu. Kemudian untuk peneliti selanjutnya diharapkan dapat menggunakan permainan dadu dalam kajian penelitian tentang aspek perkembangan anak usia dini yang lainnya.

Saran secara teoritik untuk pengembangan keilmuaan pembelajaran di PAUD, peneliti lain dapat melakukan penelitian dengan scope yang lebih luas. Penelitian juga dapat diperluas dengn menggunakan pendekatan dan desain penelitian yang berbeda. Penelitian kuantitatif dapat dilakukan dengan mengukur tingkat prososial anak usia dini dengan treatmen permainan dadu. Penelitian juga dapat diperkuat dengan pendekatan kuantitatif yang dapat memotret secara lengkap tentang fakta dibalik peningkatan 
prososial anak, respon lain dari anak usia dini, juga lingkungan sekitar yang mendukung peningkatan krmampuan prososial anak usia dini.

\section{AKNOWLEDGMENT}

Penelitian ini dilakukan sebagai bagian dari pengabdian masyarakat dosen prodi PIAUD IAIN Kendari bersama lembaga pendidikan anak usia dini di kota Kendari.

\section{DAFTAR RUJUKAN}

Ananda, Rizki dan Fadhilaturrahmi, F. (2018). Peningkatan Kemampuan Sosial Emosional melalui Permainan Kolaboratif pada Anak KB. Obsesi: Jurnal Pendidikan Anak Usia Dini, 2(1), 20-26.

Andriyani, P. W. S., Raga, G., \& Suartama, I. K. (2013). Penerapan Metode Demonstrasi Berbantuan Media Dadu Untuk Meningkatkan Kemampuan Mengenal Konsep Bilangan Pada Anak di TK Widya Suta Kerti Sulanyah. Jurnal Pendidikan Anak Usia Dini Undiksha, 1(1), 1-11.

Arikunto, S. (2009). Penelitian Tindakan Kelas. Jakarta: Bumi Aksara.

Desmita. (2013). Psikologi Perkembangan. Bandung: Remaja Rosdakarya.

Duha, Refisi dan Widiastuti, A. A. (2018). Meningkatkan Kemampuan Sosial Emosional Anak Melalui Metode Role Playing di Kelompok Bermain. Satya Widya, 34(1), 77-87.

Hurlock, E. B. (1980). Psikologi Perkembangan Suatu Pendekatan Sepanjang Rentang Kehidupan (Kelima). Jakarta: Erlangga.

Hurlock, E. B. (2013). Perkembangan Anak (Keenam). Jakarta: Erlangga.

Iskandar. (2009). Penelitian Tindakan Kelas. Jakarta: Gaung Persada Press.

Joni. (2016). Peningkatan Kemampuan Kognitif Anak dalam Kegiatan Berhitung dengan Permainan Dadu TK Mutiara Pekanbaru. Obsesi: Jurnal Pendidikan Anak Usia Dini, 2(1), 1-10.

Kebudayaan, K. P. dan. Permen Dikbud Nomor 137 tentang Standar Nasional Pendidikan Anak Usia Dini. , (2014).

Mulyasa. (2012). Manajemen PAUD. Bandung: Remaja Rosdakarya.

Nurbayani, Y. (2011). Pengaruh Penerapan Bermain Dengan Dadu Geometri Terhadap Keterampilan Sosial Dan Kemampuan Berhitung Permulaan Anak Usia Dini (Doctoral Dissertation, Universitas Pendidikan Indonesia).

Papalia, D. E. dan R. D. F. (2015). Menyelami Perkembangan Manusia. Jakarta: Salemba Humanika.

Purwanto, N. (2009). Prinsip-Prinsip dan Teknik Evaluasi Pengajaran. Bandung: Remaja Rosdakarya.

Rohmah, N., R. dan A. R. (2016). Keefektifan Pembelajaran Kooperatif melalui Media Dadu dalam Pengembangan Kemampuan Matematika Bagi Anak Usia Dini. Journal of Primary Education, 5(1), 42-48.

Rohmawati, Mirsa dan Simatupang, N. D. (2017). Pengaruh Permainan Dadu Warna- 
Warni Modifikasi Terhadap Kemampuan Menghitung Anak Usia 5-6 Tahun di TK PKK Sidomulyo Purwoasri Kediri. Jurnal PAUD Teratai, 6(3), 1-4.

Sudijono, A. (2010). Pengantar Statistik Pendidikan. Jakarta: Rineka Cipta.

Suyadi dan Ulfah, M. (2013). Konsep Dasar PAUD. Bandung: Remaja Rosdakarya.

Zaini, A. (2015). Bermain sebagai Metode untuk Pembelajaran Anak Usia Dini. Thufula: Jurnal Inovasi Pendidikan Guru Raudhatul Atfal, 3(1), 118-134.

\section{AUTHOR}

1. Nama

: La Hewi, S.Pd.I., M.Pd

NIP : 199007312019031004

Pekerjaan : Dosen Tetap PNS Prodi PIAUD IAIN Kendari

NIDN : 2031079001

Email : : lahewih15@gmail.com

2. Nama : Surpida, S.Pd.I., M.A

NIP : : 197412112005012002

Pekerjaan : Kepala RA An-Nur/Dosen LB Prodi PIAUD IAIN Kendari

Email

: virdamahdy@gmail.com 